\title{
Moravian and Inuit Encounters: Transculturation of Landscapes and Material Culture in West Greenland
}

\author{
Peter Andreas Toft ${ }^{1}$
}

(Received 17 March 2016; accepted in revised form 2 September 2016)

\begin{abstract}
From 1733 to 1900, Moravian missionaries settled in West Greenland to missionize and teach. These activities resulted in local mission and settlement layouts that followed Moravian principles and at the same time adapted to local landscapes and Inuit traditions and subsistence practices. This article explores spatial data, objects, oral tradition, and written sources from sites at Uummannaq, Akunnaat (Lichtenfels), and Kangillermiut, West Greenland. At these sites, landscape use was transculturated, and the material culture changed among both the European missionaries and the local Inuit. Moravian missionaries traded European commodities for Inuit artefacts, and an Inuit industry evolved through creating souvenirs for the missionaries. At the same time, local Inuit material culture was influenced by the presence of the Moravians, who introduced written language, administrative birth numbers, goats, and new crafts such as European-style basket weaving. The cultural encounters at the three Greenlandic sites resulted in objects and practices that were cultural composites of European and Inuit ideals and traditions.
\end{abstract}

Key words: West Greenland; Moravian missions; Inuit; material culture; landscape; transculturation; archaeology

RÉSUMÉ. De 1733 à 1900, des missionnaires moraviens se sont établis dans l'ouest du Groenland pour y édifier des missions et enseigner. Cela a donné lieu à un agencement de missions et d'établissements suivant les principes moraviens, adaptés toutefois aux paysages de la région ainsi qu'aux traditions et aux activités de subsistance des Inuits. Cet article se penche sur les données spatiales, les objets, la tradition orale et les sources écrites de sites situés à Uummannaq, Akunnaat (Lichtenfels) et Kangillermiut, dans l'ouest du Groenland. À ces sites, l'utilisation du paysage a été transculturée et la culture matérielle a été modifiée, tant chez les missionnaires européens que chez les Inuits de la région. Les missionnaires moraviens ont échangé des biens européens contre des artefacts inuits, si bien qu'il s'est formé une industrie inuite de création de souvenirs à l'intention des missionnaires. Par la même occasion, la culture matérielle locale des Inuits a été influencée par la présence des Moraviens, qui leur ont fait connaître la langue écrite, les numéros de naissance à des fins administratives, les chèvres et de nouvelles pièces d'artisanat comme les paniers nattés à l'européenne. Les rencontres culturelles aux trois sites groenlandais ont donné lieu à la création d'objets et de pratiques prenant la forme de composites culturels émanant de traditions et d'idéaux européens et inuits.

Mots clés : ouest du Groenland; mission moravienne; Inuit; culture matérielle; paysage; transculturation; archéologie

Traduit pour la revue Arctic par Nicole Giguère.

\section{INTRODUCTION}

On 20 May 1733, the cousins Mathæus and Christian Staach, as well as the carpenter Christian David, arrived at the Danish colony of Godthaab (present-day Nuuk) in West Greenland (Kleivan, 1983). These three men were the first of many European Moravian brethren who traveled to Greenland to evangelize among the Inuit alongside the Danish Lutheran priests who were already present. The Moravian initiative was approved by the Danish King Christian VI, who after 12 years of Danish colonization found the progress of the Lutheran mission too slow. The arrival of the Moravian missionaries was followed by a dramatic smallpox epidemic in Nuuk Fjord, which created a demographic void soon to be filled by settling southern Greenlanders (Gulløv, 1997:361, 401ff). From the outset, the Moravian mission was very popular, especially among southern Greenlanders, because of its emphasis on emotions, song, and other music (Kleivan, 1983:226-229). Hence a series of Moravian missions and settlements were established in Southwest Greenland during the 18th and 19th centuries (Kleivan, 1983:224). In Greenland, the Danish and the Moravians chose different settlements and areas for missionizing. In contrast to the situation in Canada, where Inuit in some settlements were affiliated with several different missions (e.g., Moravian, Pentecostal, and Catholic), Inuit in a Greenlandic settlement all belonged to the same mission (Kleivan, 1983:222-223). Both the European missionaries and the Inuit of the two missions met frequently at the trading

\footnotetext{
${ }^{1}$ The National Museum of Denmark, SILA - Arctic Centre at the Department of Modern History and World Cultures,

Frederiksholms Kanal 12, 1220 Copenhagen K, Denmark; peter.a.toft@natmus.dk

(C) The Arctic Institute of North America
} 
posts, and generally the relations between the Danish missionaries, trade company employees, and Moravian missionaries were good (Lund Jensen et al., 2011:97-100). However, the different interpretations of Christianity did sometimes create local problems. For example, Inuit of the Moravian congregations of Neu Herrnhut were punished for participating in European dances during visits at the nearby Danish mission at Godthaab (Kleivan, 1983:227). The different interpretations also meant that some Danish priests married local Inuit women, whereas their Moravian colleagues did not (Kleivan, 1983:225).

In 1900, the Moravian missionaries left Greenland officially as a result of having christened all Greenlandic Inuit in the areas surrounding their missions, but their missions and the related settlement were still inhabited by the Inuit well into the 20th century (Kleivan, 1983:232f). The end of Moravian activities in Greenland was also a consequence of the Danish defeat in the Danish-Prussian war in 1864, after which Germans were unpopular guests on Danish soil.

One of the main differences between Moravian missions in Canada and Greenland was that the former were financed by trade with the local Inuit, whereas the Danish king monopolized trade in Greenland, first through franchising it to three successive chartered private companies, and after 1776, through a state-owned institution: The Royal Greenlandic Trade Department (RGTD). The trade companies had the obligation to supply the Moravian missions as well as the Danish ones, but the former were also allowed to be partly supplied with food and objects collected by Moravian Brethren in Europe. In spite of this, the Moravian missions were very dependent on good relations with their local trade company merchant (Lund Jensen et al., 2011:97-100). While Moravians in Greenland were not allowed to set up trading posts at their missions, they were permitted to barter European goods for personal necessities like local food and products (Kleivan, 1983:226). This trade is very visible in the material culture of the Inuit living at the missions, where European commodities entered their daily lives. At the same time, local products were altered to fit European taste, which led to small-scale production of souvenirs for the European missionaries. Such objects were often cultural composites of Inuit and European traditions and ideals, and often the location, layout, and features of Moravian missions and settlements also reflected this composite culture. This case fits well with Deagan's concept of transculturation (Deagan, 1998), which views cultural influence as a dialectic between groups involved in colonial encounters, and not as unidirectional from European colonizers to the colonized, as assumed in earlier acculturation models. According to Deagan, transculturation processes result in new practices and objects with multiple origins and agents. Such practices and objects combine and transform pre-contact traditions and ideals of all groups in the specific local and historic context.

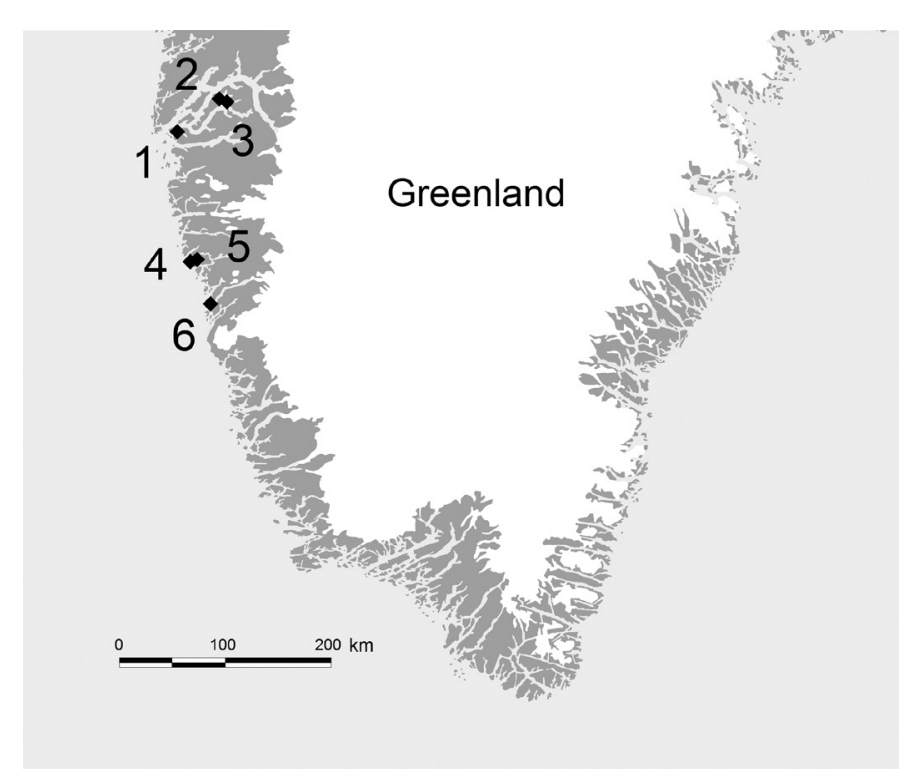

FIG. 1. Map of southern Greenland showing the sites mentioned in the text: 1: Neu Herrnhut and Godthaab (Nuuk), 2: Qoornoq, 3: Uummannaq, 4: Lichtenfels, 5: Fiskenæsset, 6: Kangillermiut. Map: P.A. Toft.

Transculturation of landscape and material culture is the main theme of this article, which explores the results of survey work conducted at the Lichtenfels Mission and Kangillermiut settlement in the landscape between Qeqertarsuatsiaat and Paamiut in 2012-13 (Fig. 1) and the excavation at the Uummannaq mission in the Nuuk Fjord carried out as a part of the Steatite Objects Analysis Project (SOAP) in 2007.

\section{HISTORY OF THE THREE SITES}

The oldest of the three sites is the Lichtenfels mission, present-day Akunnaat. The mission was founded in 1758 west of Fiskenæsset (now Qeqertarsuatsiaat), the Danish trade station established four years earlier (Bobé, 1921:291). Whether the place was settled before the arrival of the Moravians is uncertain. The Inuit place name Akunnaat means 'the place that is not average,' that is, where there is rarely a shortage of game (Knudsen et al., 2014:6.18). In the 19th century, the mission was populated by 128 to 367 Inuit, but there were never more than 13 European missionaries and their family members. In the first half of the 20th century, 48-72 Inuit lived at the settlement (RA, $1834,1845,1850,1860,1870,1901,1911,1945)$.

The Kangillermiut settlement was probably founded in the mid-19th century, since its first birth records, according to ministerial books, are from 1850 (NKA, n.d.). In 1911, 17 Inuit lived at the settlement (RA, 1911).

The latest of the sites, the Uummannaq mission, was founded $60 \mathrm{~km}$ inside the Nuuk Fjord system in 1861 by Inuit and European missionaries from the Neu Herrnhut mission and Inuit from the nearby site of Kukit. The mission's founding was a response to a rising population 
inside Nuuk Fjord. Many Inuit in this area were already Christian, and some were connected to the Moravian mission (Bendixen, 1921:256; Kleivan, 1983:225). In 1870, 68 Inuit lived at the site, together with two German missionaries. By 1901, the Inuit population had risen to 79 people (RA, 1870, 1901).

From the censuses, it is clear that the Inuit from the Moravian settlements Kangillermiut and Lichtenfels often married Inuit from the Danish mission and trading station at Fiskenæsset. At Uummannaq, the Inuit mostly married people from the nearby trade station at Qoornoq; some were part of the Moravian congregation, while others belonged to the Danish mission. Other Uummannaq Inuit found their partners farther away at the Neu Herrnhut mission (RA, 1834, 1845, 1850, 1860, 1870, 1901).

All three settlements were abandoned by their European missionaries in 1900, but continued as Inuit settlements until 1951. At that time, many smaller Greenlandic settlements were closed down by a political reform, during which people were relocated to larger settlements (Gulløv, 1983:72).

\section{SETTLEMENT LAYOUT AND STRUCTURES}

\section{Lichtenfels (Akunnaat)}

The Lichtenfels mission is located in a protected cove on the north side of an island $3.5 \mathrm{~km}$ west of the trading post at Fiskenæsset (Qeqertarsuatsiaat). The location provided not only protection against the wind and waves in the fjord, but also access to seasonal game such as char (Salvelinus alpinus) and ringed seals (Pusa hispida) inside the fjord and harp seals (Pagophilus groenlandicus) migrating along the coast outside the nearby mouth of the fjord in the spring and winter. In January and February, the local Inuit went seal hunting in the Ikerasaarsuuk and Kigutulik Fjords. In March and April, game was scarce, so the Inuit stayed on site, relying on fishing and hunting the seals that were resting on the ice. From July people turned to charfishing and hunting hooded seals (Cystophora cristata) on the outer skerries. Seal hunting continued into October and was supplemented by hunting foxes and birds on the outer skerries in the last two months of the year (Bendixen, 1921:265-266). No sources reveal whether Lichtenfels was inhabited prior to the establishment of the Moravian mission, but the site location fits well with the traditional Inuit settlement pattern. On the other hand, the placement of the site near the Danish trading post at Fiskenæsset suited the Inuit desire for trade and was also convenient for the European missionaries, who were largely dependent on supplies from the trading post.

The layout of the Lichtenfels mission and settlement is influenced by Moravian architectural ideals, Inuit traditions, and the adaptation of these to the local landscape. Like the first Moravian mission at Neu Herrnhut, Lichtenfels has a symmetrical layout, with the church in the centre (Fig. 2:
Feature R) flanked by houses to the SSE and NW. The slope in front of the church to the northeast is left without features except for a pathway edged with stones (AL) running from the shore to the church. Even though it is not possible to date the houses of the site on the basis of the present survey work, it is evident that this space was respected even after the departure of the Moravians from Greenland in 1900, as no houses block the view from the church to the shore. Also in accordance with the missionaries' architectural ideals is the presence of a garden at the church, which can be observed both on historical photos and in the landscape today (Fig. 3). But the location of the garden behind the church is unusual for a Moravian mission. An echo of the Moravian ideal of placing the garden in front of churches can be seen in a depiction of Lichtenfels in a publication from 1874 (Hyde et al., 1874: 32f), which contradicts the real location of the garden captured in historic photos from the late 19th and early 20th centuries. In addition, no evidence of a front garden is evident in the landscape today. The location of the garden is correct in the 18th century depiction of Lichtenfels in David Crantz's Historie von Grönland (Fig. 4). This engraving displays Moravian ideals of symmetry and portrays the garden as rectangular and divided into four quadrants; however, this ideal had to be adapted to the contours of the local landscape (Fig. 2: Feature V). The mountainside at the northwest wall of the church turns towards the SSE; as a result, one of the garden walls is diagonal and not in line with the church wall. For unknown reasons the northernmost wall is not in line with the southeast wall of the church in the half lying most to the east. The asymmetrical shape of the garden is not very faithful to its European ideals, and this would have been even more the case if it were arranged in quadrants as portrayed on Crantz's engraving. Such an arrangement is not detectable in the landscape today. Making the location and shape of the garden fit better to Moravian ideals would have been possible in another part of the landscape, but the church location was determined by the best place to land boats. Obviously the Moravians wanted the church to be the first building visitors saw as they were going ashore.

Other features at Lichtenfels are also connected to the presence of Europeans. One of these is a trapezoid-shaped area of land (Fig. 2: Feature T) with vegetation similar to that of the garden and three drainage ditches. This area was probably an extension of the 18th century garden and is present on Thomas Krabbe's 1895 photo (Fig. 3), but not in Crantz's idealized 18th century engraving. The date of this extension is uncertain. Between the two gardens runs a stone-edged path (Feature U), which may have extended up the mountainside to the plateau on which the settlement's well (Feature O) and the wooden house on a stone foundation (Feature N) are situated (Fig. 2). The latter used to be the settlement's mortuary, according to Hans Henrik Berthelsen, a resident of Qeqertarsuatsiaat. A third stoneedged path (Fig. 2: Feature $\mathrm{X}$ ) is seen on the raised terrain west of the church running from the entrance of Feature W, a rectangular winter house built of stone and turf. The 


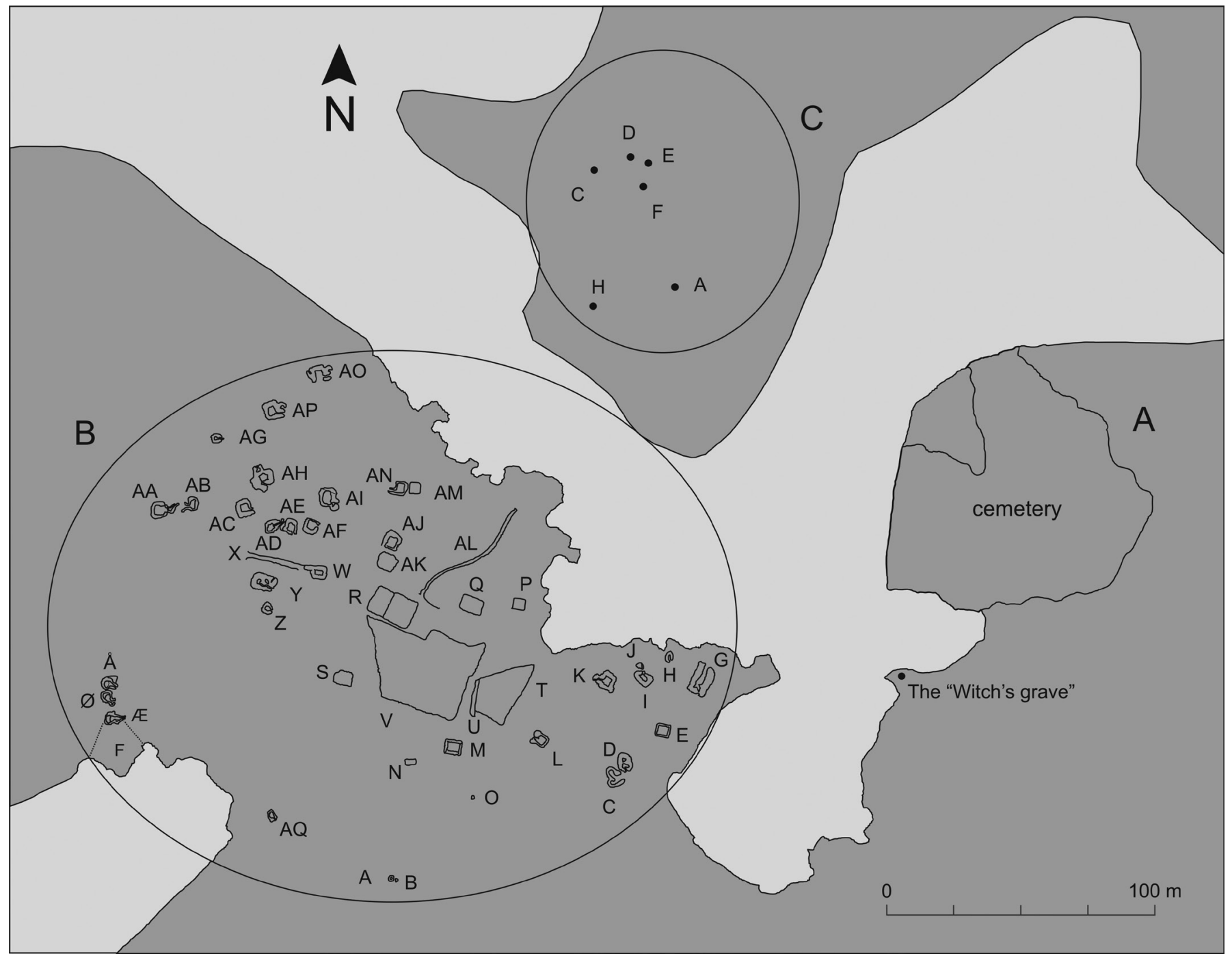

FIG. 2. Map of the Lichtenfels site (modified from Knudsen et al., 2014:6.18). Zone A (cemetery area). Zone B (Mission and Inuit settlement): Outlook structure (A), fox trap (B), store house $(J)$, mortuary $(N)$, well $(O)$, church $(R)$, garden extension $(T)$, garden $(V)$, stone-edged paths $(U, X, A L)$. Turf houses $(Æ, \varnothing)$. Stone houses (G, H, I, K, A, AA, AB, AC, AE, AG, AH, AI, AN, AO, AP). Stone and turf houses (C, D, W, Y, Z, AD, AF). Late Inuit houses with cement foundation (E, L, M, P, Q, S, AM). Midden (F). Four-sided structures (AJ, AK). Oval stone structure (AQ). Zone C (Oldest settlement area): Tent houses (A, E). Stone house (C). Turf house (D). Cache (F). Fox trap (H).

function of this path remains obscure, as it ends in the landscape without any direct connection to other features.

\section{Kangillermiut}

Unlike Lichtenfels and Uummannaq, Kangillermiut was a settlement of Inuit followers rather than a mission. The site is located in a small bay just inside the mouth of the Bjørnesundet fjord, on the north side of its course, protected by a couple of islands. Accounts from the early 20 th century reveal a varied and mobile subsistence strategy among the Inuit of Kangillermiut, which was probably identical to the practice of the last half of the 19th century. The location of the site 2-3 km from the coast (Bendixen, 1921:268f) makes it ideal for the exploitation of coastal resources: ringed seals that commonly rest on the ice on mild days of the early spring; migrating Common Eiders (Somateria mollissima) in April; and harp seal, Arctic fox (Vulpes lagopus), and other birds in October. In July and early August, people moved from Kangillermiut to the inner part of Bjørnesundet to fish for cod (Gadus morhua), which they used for trading at Fiskenæsset $43 \mathrm{~km}$ to the north. In contrast to the situation at Uummannaq and Lichtenfels, Kangillermiut residents had to travel for two days by kayak to obtain European commodities. In addition, traveling north was often difficult in the wintertime because of local ice conditions (Bendixen, 1921:268f). Consequently, the Inuit of Kangillermiut mostly went to Qeqertarsuatsiaat (Fiskenæsset) in early spring to catch hooded seals and in August and September to fish cod and hunt caribou (Rangifer tarandus). In the late summer, the Inuit ventured $10-17 \mathrm{~km}$ south of Kangillermiut to catch capelin (Mallotus villosus) and harp seals in three neighbouring fjords. Eleven fox traps, three shelters, two caches, two cairns, and three graves are scattered on the mountainside to the northeast at some distance from the settlement. These 



FIG. 3. Photo of the garden at the Lichtenfels Church, viewed from the east. The garden is visible (A) in the vegetation today (photo by P.A. Toft in 2013) and (B) in the historical photo taken by Thomas Krabbe in 1895 (National Museum of Denmark, L.136).

features are most likely associated with an earlier hunting camp in the area rather than the 19th century settlement. The settlement consists of an earlier part with turf houses and $\mathrm{u}$-shaped tent foundations made of stone, located south of the point (Fig. 5: Features W, X, Y, Z, Æ, and Ø), and a later part with buildings on cement foundations or stone walls located on the point (Fig. 5: Features AA, AB, AC, $\mathrm{AD}$, and $\AA$ ) just east of the old cemetery (AE) and north of a collapsed stone grave (Fig. 5: Feature AI). Far to the east lie the five most recent graves in a separate cemetery (Fig. 5: Feature AJ; Knudsen et al., 2014:6.129-6.135). The layout of the Kangillermiut settlement resembles that of other Inuit settlements, rather than that of the Moravian missions at Neu Herrnhut, Lichtenfels, and Uummannaq, which to some extent were influenced by ideals of Moravian architecture. The location of the site in an area that provides nearby resources during some parts of the year and a maximum of two days of traveling to seasonally supplementary resources to the north and south is at least to some extent a traditional Inuit practice. However, the location may be equally well connected to the possibility of a relatively short travel time to the Lichtenfels mission for mass and other religious events. The nearby mission may have inspired the Inuit to settle in an area halfway between the two seasonal hotspots. At the same time, this spot was conveniently close to a Danish trading post.

\section{Uummannaq}

The latest of the three Moravian settlements is Uummannaq, situated $70 \mathrm{~km}$ inside the Nuuk Fjord. This mission was built on a small island at the nexus of several side fjords (Ujarassuit Paavat, Kapisillit Kangerluat and Qoornup Sullua), which shortened the transport to and from other Inuit settlements of the inner fjord. Like Lichtenfels, the Uummannaq mission was placed close to a trading post of the Royal Greenlandic Trade Department, in this case at the settlement of Qoornoq lying $15 \mathrm{~km}$ to the west,

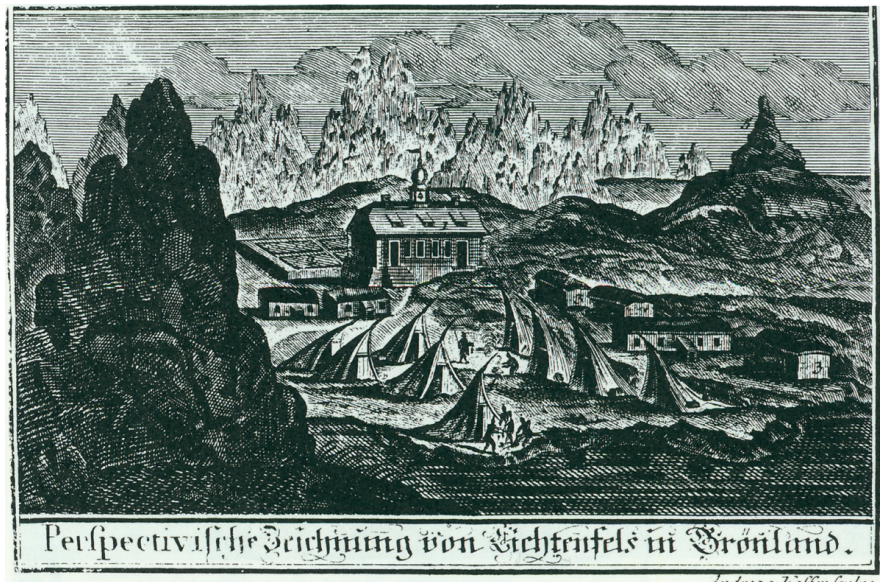

FIG. 4. 18th century illustration of the Lichtenfels mission (Crantz, 1765: Plate VIII). Inuit summer tents are shown in the foreground.

facilitating access to European supplies for the missionaries and regular trade for their Inuit followers. The mission, located in a small shallow bay on the southeastern coast of Uummannaq Island, was $500 \mathrm{~m}$ south of a series of steatite deposits, which provided raw materials for production of objects for local consumption and trade. The location of the site also supported year-round habitation, as indicated by the faunal material in one of the settlement's middens, which contains bones of typical summer species like harp seal and bearded seal (Erignathus barbatus), porpoise (Phocoena phocoena), but also of species available all year, including ringed seal, narwhal (Monodon monoceros), and beluga whale (Delphinapterus leucas), Arctic hare (Lepus arcticus), and Arctic fox. The many bones of redfish (Sebastes marinus), cod, halibut (Hippoglosus hippoglosus), and dab (Hippoglossoides platessoides) make it clear that the settlement also relied heavily on fishing. The many bones of migratory and resident bird species also demonstrate the site's potential for permanent habitation (Toft, 2011; Toft and Gulløv, 2011). In this respect, the missions favoured a 


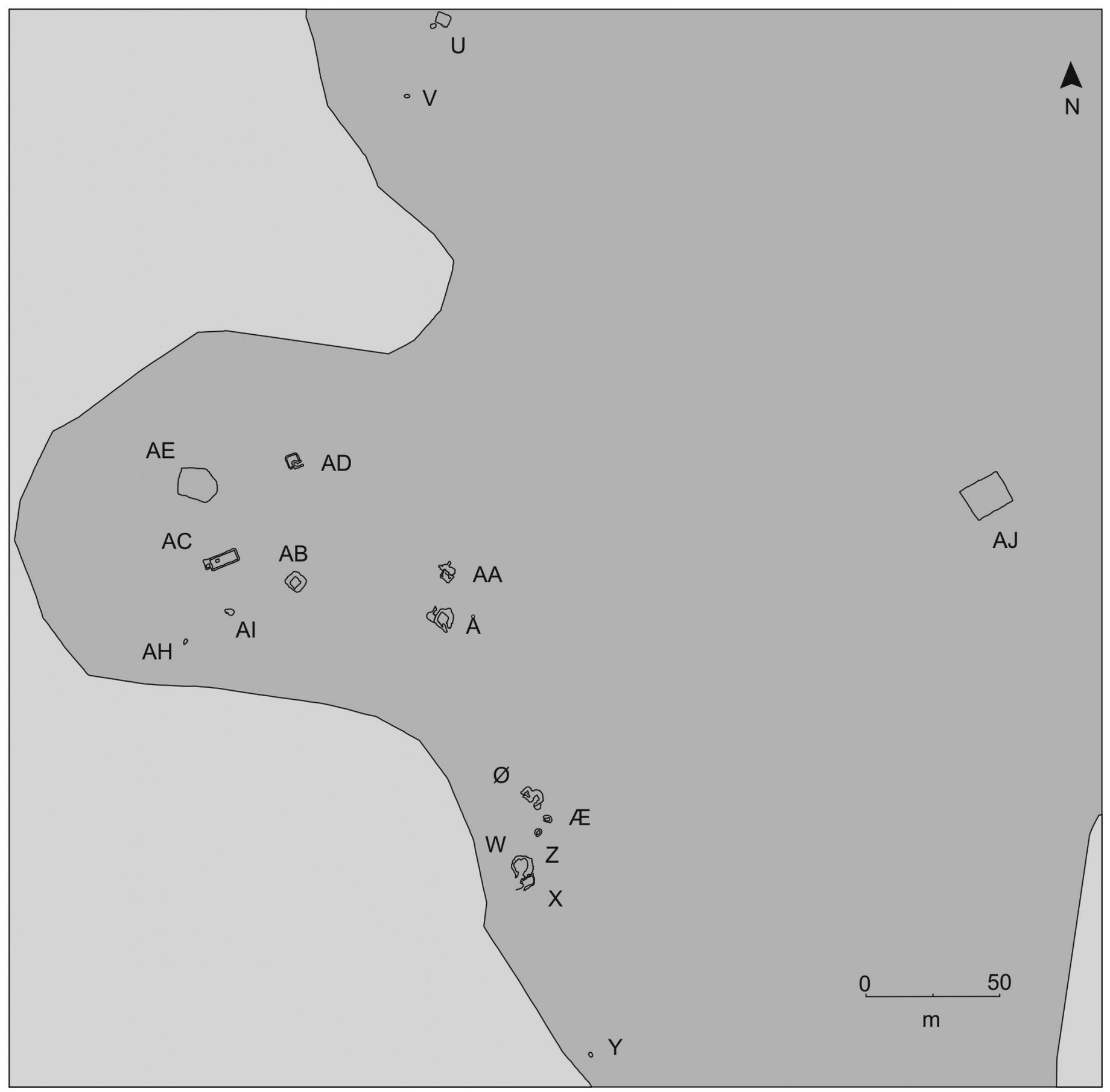

FIG. 5. Map of the Kangillermiut settlement (modified from Knudsen et al., 2014:6.122). Houses of the 19th century settlement (X, Y, Z, Æ, Ø). Houses of the 20th century settlement (U, AA, AB, AC, AD, ̊). 19th century cemetery (AE). 20th century cemetery (AJ). Stone grave (AI). Fox traps (V, AH).

traditional Inuit subsistence pattern. However, the layout of the settlement is a cultural compromise.

The garden at Uummannaq is located in front of the church, with both church and garden facing the entrance to the site, a characteristic that is identical to the mother mission of Herrnhut in Saxony (Fig. 6: Feature A). But in contrast to this ideal, and to the layout of the early Moravian missions in West Greenland, Neu Herrnhut, and
Lichtenfels, the space in front of the garden at Uummannaq is occupied by Inuit houses (Fig. 6: Features 10-12), at least some of which must have been inhabited prior to the departure of the missionaries in 1900 . The positions of these houses at the small bay, rather than flanking the church, follow an Inuit settlement layout that prioritizes the ease of everyday activities, such as slaughtering sea animals and dragging boats to the settlement. 


\section{CEMETERIES AND GRAVES: DISTANCE TO THE DEAD}

The burial features connected to Moravian missions show developments from the earliest settlement at Lichtenfels to the latest at Uummannaq. The cemetery at Lichtenfels was in use for the longest period and thus holds the largest number of graves. During the 2013 survey, 252 graves were documented by photography and position, and 112 of these were described in detail. It is estimated that the graves documented amount to one-third to one-half of the total number of graves (Knudsen et al., 2014:6.19). The Lichtenfels cemetery is situated on a large rock outcrop farther inside the cove at a walking distance of $250 \mathrm{~m}$ to the nearest house of the settlement (Fig. 2). The majority of graves are situated at the easternmost end of the outcrop. Many of these are turf-built, and some have remnants of wooden crosses assembled with machine-made wire nails, which postdate 1850 (Nelson, 1968). Hence the cemetery seems to have been established at its western end, where many stone-built graves are placed on high ground that offers a good view over the land and the cove. If this hypothesis holds true, the distance from cemetery to settlement is extended by $100 \mathrm{~m}$.

The high and distant location choice fits well into Inuit traditions of giving the deceased a good view of the surrounding landscape and at the same time having the spirits of the dead at a proper distance from the settlements (Gilberg and Petersen, 1991:59). That this traditional Inuit perception of the dead and their spirits was still alive at Lichtenfels is further supported by local oral tradition. One circular stone grave was built on a small rock west of the main cemetery area (Fig. 2: "Witch's grave"). This rock becomes a small island during high tide, which separates it from the cemetery and the settlement. It is said that the grave holds the body of a local witch (Knudsen et al., 2014:6.19). Distancing the mortuary from the settlement as described above may be seen in the same light, even though the presence of the well on the same plateau suggests that the place was visited daily, at least during some periods. The wooden floor of the mortuary, visible on the surface today, was assembled with wire nails, which indicate the floor was constructed after the 1850s. However, the distance between settlement, mortuary, and burials could have had a practical function, keeping the smell of decomposing bodies away from the dwelling area and outdoor activities.

Other graves in the cemetery (Zone A) also reveal traditional Inuit practices that survived the introduction of Christianity and exposure to European burial ideals. One such practice, known in at least two cases, is the burial of multiple persons in the same grave. In one of these, Grave $\mathrm{Z}$, two skulls are visible from the outside of the disturbed rectangular stone-built grave (Knudsen et al., 2014:6.26). Farther to the west in Grave CÆ, the presence of two crania and three femurs among eight ribs, one mandible, and one humerus shows that at least two individuals were buried here. The cranial sutures indicate that one of the individuals
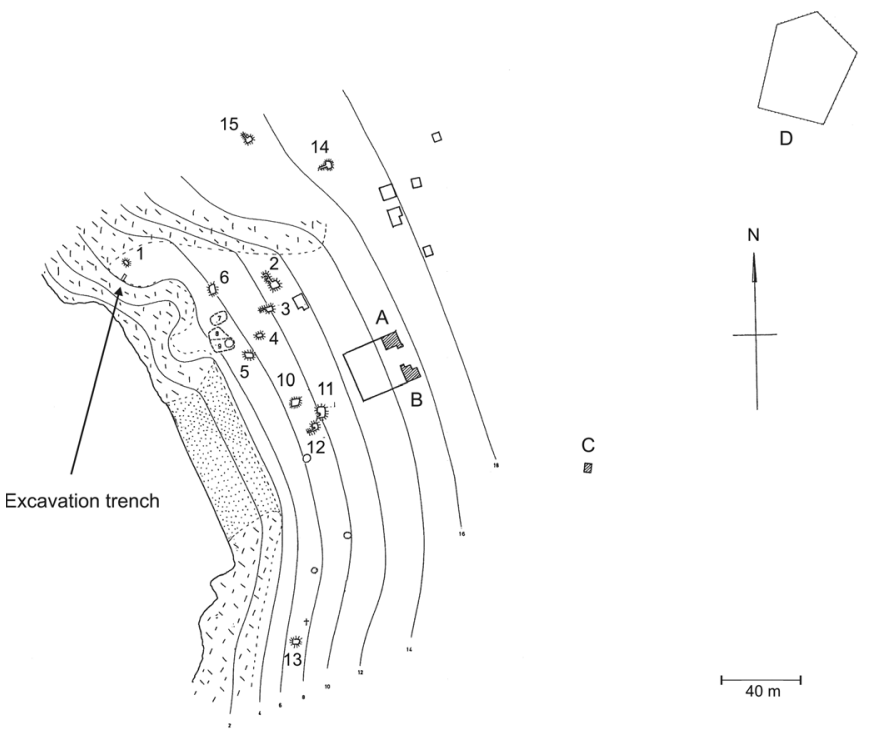

C

FIG. 6. Map of the Uummannaq site (modified from Toft and Gulløv, 2011:7). A: church. B: school building. C: goat stable. D: cemetery. 1-15: Inuit houses. A cross indicates one stone grave, and circles represent Inuit tent rings.

must have been a juvenile and the other an adult (Knudsen et al., 2014:6.49). In addition to the two graves described above, Graves BV and AX, judging by their size, may have housed more than one individual. Grave BV measures $3.6 \times$ $1.75 \mathrm{~m}$, whereas Grave AX is slightly larger at $2.4 \times 3.27 \mathrm{~m}$ (Knudsen et al., 2014:6.33, 6.40). The latter is in the same area as the turf graves, suggesting a late date.

Another precolonial Inuit burial custom is the deposition in or beside the grave of objects for use in the afterlife (Gilberg and Petersen, 1991:58). At Lichtenfels, the use of such burial gifts is observable in Grave CX, one of the disturbed oval stone graves (Knudsen et al., 2014:6.48). Beside a humerus, a white 18th century Dutch glass bead was deposited on top of a copper cauldron rim-fragment. Other visible bones included a second humerus, one radius, one ulna, and a maxilla fragment. This grave shows that the custom of depositing burial gifts survived into the second half of the 18th century even at a missions like Lichtenfels. Traces of Inuit burial customs in five out of 112 graves with detailed documentation are at least faint echoes of earlier practices, but many more traces could exist, as only those traces visible from the outside (e.g., in graves disturbed by Arctic foxes) can be recorded.

The question of who was buried in graves built of stone and who in those of turf in the younger part of the cemetery remains unanswered. Some of these graves may have been built in the last decades of the Moravian presence at the site. However, both grave types in some cases contain wooden coffins or were adorned with wooden crosses, which may have marked them as graves of the European missionaries. One of these graves also stands out as originally having had a wooden fence, which is only partially preserved today. None of the graves in the investigated area have preserved gravestones that could have provided clues to the identity of the deceased. Gravestones used to be plentiful 
at the cemetery, but many have been removed from the site. According to local information, the disappearance of the stones was possibly connected to a helicopter visit by Europeans in the 1970s (Knudsen et al., 2014:6.19).

The oldest cemetery at Kangillermiut was founded almost a century later than that at Lichtenfels. Thus the Kangillermiut cemetery has many features in common with the latest part of the Lichtenfels cemetery. But the two cemeteries also display some marked differences. At Kangillermiut, the oldest cemetery is located closer to the houses of the oldest part of the settlement, at a distance of $175 \mathrm{~m}$ (Fig. 5). If the houses of the western and younger part of the settlement had earlier predecessors, the distance to the nearest houses could have been as close as $50 \mathrm{~m}$. At least the location must be seen as a cultural compromise between European ideals of closeness and Inuit ones of distance. This location was an alternative to placing the cemetery on the mountainside between the settlement and the new cemetery, Feature AJ. Because of the site's smaller population and shorter history, the old cemetery at Kangillermiut contains only 24 graves. It is situated on a slightly raised rock surrounded by a stone dyke built on the east side and on the eastern half of its north and south sides (Fig. 5: Feature AE). On its easternmost side, the borders of the cemetery are delimited by the foot of the raised rock. Both the location and the dyke must be seen as the result of European influence. The cemetery shows an even clearer distribution of grave types than at Lichtenfels, with stone graves exclusively in the western part and turf-built graves in the easternmost end of the cemetery. Many of the stone graves are built on the top of the low rock, and most of the turf graves are adjacent to the stone dyke edging their part of the cemetery. Only one of the turf graves, grave AF, had a wooden fence (Knudsen et al., 2014:6.129), whereas both grave types have partly preserved wooden crosses. No gravestones were preserved.

The site's function as a settlement of followers, rather than a mission, speaks against an interpretation of the turf graves as missionary graves, as at Lichtenfels. The distribution of the two grave types at the two cemeteries makes a temporal difference in the use of stone and turf graves probable. This change could in itself be seen as European influence in burial customs. But on the basis of survey work alone, the introduction of turf graves is difficult to date. Only one grave at Kangillermiut, the stone grave AI, can be dated by the wire nails used in its wooden cross (Knudsen et al., 2014:6.132). At Lichtenfels, 10 graves have wire nails in the construction of their cross or coffin. Of these, seven are built of turf, two of stone, and one of a combination of the two materials (Knudsen et al., 2014:6.20-6.50). With the earliest manufacture of wire nails around 1850 (Nelson, 1968), the introduction of turf graves could be limited to the last 50 years of Moravian presence in Greenland. But this grave form may equally be a phenomenon of the first half of the 20th century. Even at that late date, the introduction of turf graves could be argued to be the result of exposure to European burial ideals.
The cemetery at Uummannaq is situated on a flat plain only $200 \mathrm{~m}$ north of the settlement. In size and layout, it mostly resembles the cemetery of Kangillermiut (Fig. 6). The cemetery contains only a small number of graves, found close together, but is not delimited by dykes as at Kangillermiut. However, wooden fence posts are placed around the cemetery. From their state of preservation, it is likely that they were erected in the 20th century, after the departure of the Moravians. The cemetery's proximity to the settlement represents a break in burial customs on the island. Two stone graves are found $1.6 \mathrm{~km}$ southeast of the mission and $2.3 \mathrm{~km} \mathrm{SSE}$ of an earlier 18th century Inuit settlement on the west side of the Island (Toft and Gulløv, 2011). These two graves correspond well with earlier Inuit burial traditions, as they are lying high on the mountainside with a spectacular view of the neighbouring island of Qeqertarssuaq and the watercourse called Uummannap Sullua to the south (Fig. 7).

The majority of the graves in the cemetery are of stone, quite low and lying close together. These graves can be linked to individual Inuit mission community members. In the eastern end of the cemetery are three graves with gravestones for European Moravian missionaries. One stone rests over Helena Gaertner, buried in 1899, who was born at the main mission of Neu Herrnhut one year earlier (Toft, 2011). Another was raised to commemorate a Danish Moravian, Marie Foged, who was born in a village outside the Moravian mission in Christiansfeld in 1850 and died in 1885. The inscription on the third gravestone tells the fate of another woman, Auguste Elisabeth Schmiedecke, born Koch, who began her life in Berlin 25 years prior to her death in 1869. These three graves were dug into the ground in a typical European fashion rather than built on top of it. Thus, the use of gravestones and the inhumation seems to be a late grave form reserved for European missionaries.

With its location, inhumation grave forms, and low stone graves, the Uummannaq cemetery seems to be the one diverging most from earlier Inuit traditions, which is consistent with its late date. At the same time, it is the only one of the three cemeteries where the missionary graves are marked in a special way.

\section{NEW OBJECTS: TRADE, CRAFTS AND KNOWLEDGE}

In addition to the change in landscape use, new and unique practices developed at the Greenlandic Moravian missions. The physical manifestations of this process, in the form of objects, were found through small-scale excavation in a midden of an Inuit house at Uummannaq (Fig. 6), but are equally visible in the many things that Moravians brought back with them to Europe. These objects can be studied at the Museum für Völkerkunde at the mother mission in Herrnhut, Saxony. One of these objects, an embroidered skin shoe, was collected by the Moravian sister Koch. This could either be Auguste Elisabeth Koch, 


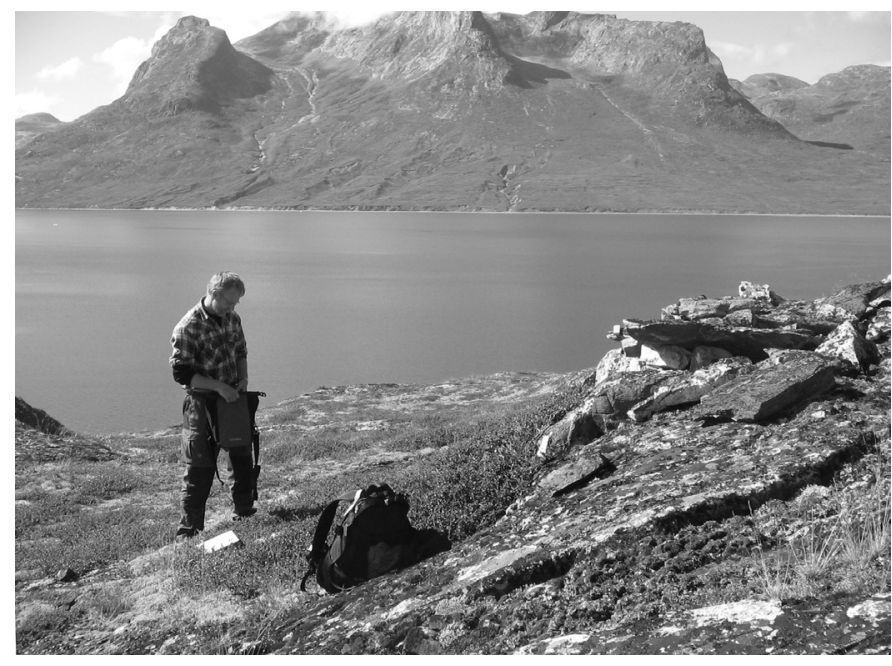

FIG. 7. Two graves SE of the Uummannaq mission. Photo: J. Winther Johannsen.

who was buried at Uummannaq, or Johanne Koch, who lived in Neu Herrnhut during 1870-72 and on Uummannaq during 1872-75. Both women were the wives of Ferdinand Wilhelm Schmiedecke, who married Johanne after Auguste's death in 1869 (Lund Jensen et al., 2011:257). Whether the shoe was produced on Uummannaq or in Neu Herrnhut remains uncertain; indeed, many other items in the Museum für Völkerkunde have even less provenience information. Nevertheless, the production of a few objects, including at least one coiled grass basket and a traditional triangular soapstone lamp, can be traced to Uummannaq Island (Lund Jensen et al., 2011:256, 275f).

While the lamp was obviously of Inuit manufacture, the basket form, with its openwork decoration, is very European in style (Fig. 8). In Greenland, making coiled baskets of lyme grass (Leymus arenarius) using needlebinding can in a single case be traced back to the earliest Thule culture of the 12th and 13th centuries (Holtved, 1944:266; Haagen, 2007). But the shape and decoration of the baskets in the Museum für Völkerkunde are clearly inspired by European basketry traditions, which women like Auguste must have passed on, along with other suitable women's activities, to their Inuit sisters.

This morphological legacy lives on today in a variety of forms, such as fruit baskets, dish mats, sewing baskets, and bread trays (Haagen, 2007). This style of basketry, called ivit in Greenlandic, was practiced mainly on sites (including Uummannaq) where lyme grass was plentiful, and it is also generally connected to sites of the Moravian congregations. Here the craft of ivit has survived: at the 1971 basket makers' meeting in Nuuk, 14 out of 21 women came from former Moravian missions and settlements (Christensen, 1972), and the majority had roots in Uummannaq.

Whether the technique of making European-style coiled baskets continues an earlier Inuit tradition or was reintroduced by the Moravians has been debated for the grasswork in both Labrador and Alaska. Hawkes $(1916: 103-104)$ argued that the technique was transferred

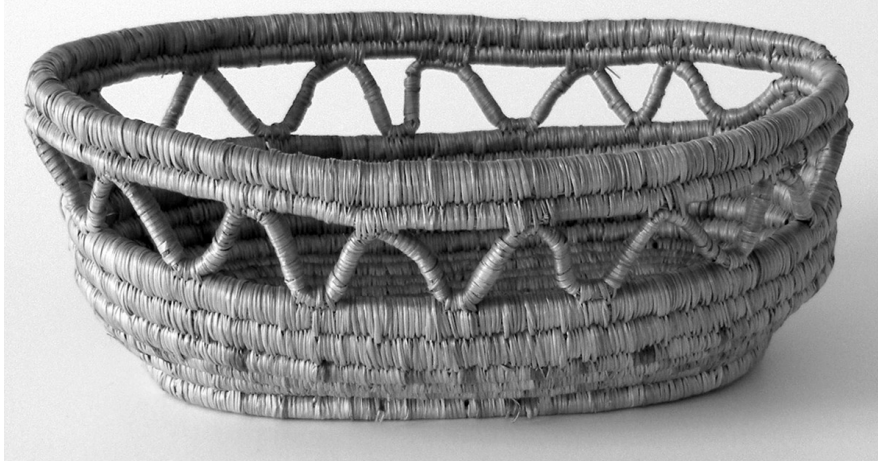

FIG. 8. Lyme grass basket from Uummannaq kept at the Museum für Völkerkunde, Herrnhut (Inv. No. 67821). Length: $20 \mathrm{~cm}$. Photo: Museum für Völkerkunde, Herrnhut.

from Alaskan Inuit to Labrador, where unique forms of decoration evolved, including the double curved line. In contrast, Lighthall in 1941 (as cited in Igloliorte, 2013:290) stated that Labrador Inuit learned grasswork from the Moravians. Others had argued previously for Norse roots for this craft (Mason, 1904:378). In the most recent work on Labrador grasswork, Igloliorte (2013:288-290) argued for a diffusion of grasswork technology from Alaska to Labrador, using a lack of grass basketry in Greenland as an argument against a Norse or Moravian origin of the craft.

But the Greenlandic grasswork in Early Thule culture and at the Greenlandic Moravian missions described above could support an Inuit or Norse origin for the single find from Inglefield Land and equally well show evidence of a Moravian origin for the 19th century material. So far, no material supports a connection between the Greenlandic Early Thule basketry and the 19th century baskets of the Moravian missions. In contrast, the likeness in form of the Labrador and Greenlandic mission material makes a strong case to support European inspiration for the morphology of grasswork and also reveals, as in the Yup'ik case (Lee, 2004), that grasswork production was systematically encouraged at the late 19th century Moravian missions. The technique could, as suggested, have traveled from Siberia to the Inupiaq of the Bering Sea and farther on to the Yupik and Labrador Inuit in historic times. But the inspiration and demand for new forms arose in the context of cultural encounters such as missions, or in new markets: for example, the wives of Newfoundland fishermen considered coiled baskets to be costly and valued items (MacGrath, 1979:49).

The Moravian missionaries became a market not only for domestic European-style objects, but also for genuine souvenirs produced by the Inuit. Both kinds of objects are preserved in the Museum für Völkerkunde. The Moravians used skin embroidery in the form of shoes, table mats, and desk pads. But models of traditional Inuit objects such as caps, women's trousers, boots and parkas, gut skin anoraks, hunting weapons, kayaks, soapstone lamps, summer tents, and turf houses also found their way to Saxony with returning missionaries, as did figurines depicting activities 
such as dog-sledging and animal flensing. Actual hunting and sewing tools, as well as toys, were shipped to Europe along with ancient Palaeo-Eskimo stone tools (Lund Jensen et al., 2011:264-267). The Museum für Völkerkunde collection illuminates only what the Europeans received in exchanges taking place at the missions.

The material of the Uummannaq midden, in contrast, sheds light on some of the commodities that were given in return and how the Moravian presence affected Inuit material culture.

The small excavation $\left(3 \mathrm{~m}^{2}\right)$ in 2007 (Fig. 6) yielded settlement material culture with a very high frequency of European commodities. Whether these objects originated from trade with the missionaries of Uummannaq or were bought at the nearby trading post at Qoornoq is in most cases difficult to determine. Many types of glass beads, metal objects, and ceramics would have been present in both contexts, and apart from objects gathered at the European congregations and sent to Greenland, the Greenlandic Moravian missions were partly supplied by the Royal Greenlandic Trade Department. However, some commodities were not for sale in the RGTD shops and must have been provided by Moravian missionaries.

Until 1834, the sale of European food to the Greenlandic Inuit was forbidden apart from coffee, tea, sugar, sugar candy, peas, meals and bread, which were permitted for sale in 1806 (Bendixen, 1917). This restriction came out of concern for making the Inuit too dependent on European food, which would destroy RGTD's possibilities of making a profit on fur, blubber, and baleen at the European market. At the time of the Uummannaq mission, this ban was no longer in effect. One type of food that may have been provided by the missionaries was represented by a cherry stone found in the Inuit midden. Dried cherries were available in the colonial shops, but at the same time, the missionaries used them as a reward for progress in literacy. The same practice was seen at contemporary Danish missions (Kragh, 1875:884, 88, 201, 279). But goat meat, according to the price lists of the RGTD, was not available in the colonial stores of the late 19th century. Consequently, the three goat bones in the midden must have come from the missionaries' goats, which were kept in a stable southeast of the chapel (Fig. 6: Feature C).

A number of other types of European objects were found in the midden. One example is a European leather shoe with a square toe. In Europe, it would have been regarded as a man's shoe, but it may have been considered suitable for either men or women among the Inuit. The height of its wearer, calculated from its length, was $136-156 \mathrm{~cm}$. The anthropological measurements produced in the same period suggest that the shoe was worn by a young person (Hansen, 1893:183). Like the shoe, the vessels represented by the 318 sherds of earthenware, faience, and porcelain found in the midden were probably used for the same purpose as in Europe, in this case making and serving food. Nonetheless, the life cycle of the vessels also points to pre-contact Inuit traditions. The Uummannaq ceramic material has a very

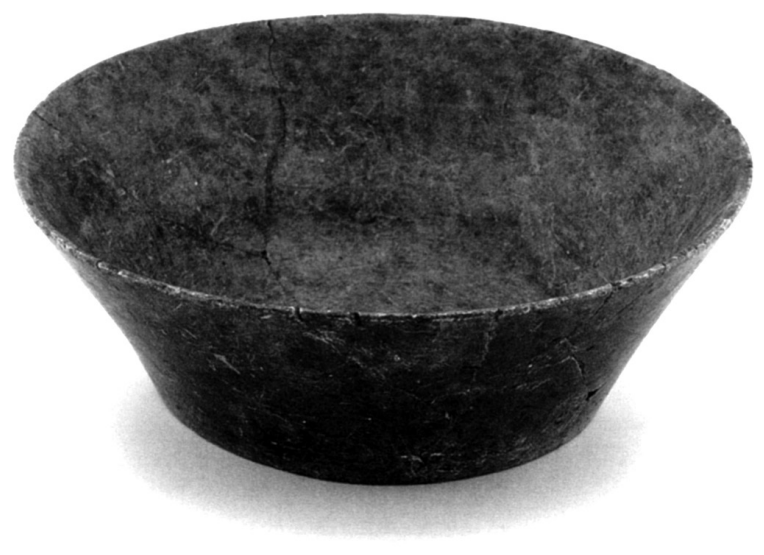

FIG. 9. European style steatite bowl kept at the Museum für Völkerkunde, Herrnhut (Inv. No. 67790). Photo: Museum für Völkerkunde, Herrnhut.

high frequency of mending holes, which is far higher than in contemporary ceramic materials from Danish urban excavations. The same phenomenon is known from the ceramics found at the Moravian missions at Hebron and Nain in Labrador (Cabak and Loring, 2000:24; Loring and Arendt, 2009:51), where access to European commodities was even more direct than at Uummannaq because the Moravians in Canada were under no trade restrictions. In both cases, the Inuit treated the ceramics according to the same tradition as their predecessors, the soapstone vessels.

On Uummannaq Island, the local soapstone gave rise to a specialized souvenir production, equally visible in the collections of the Museum für Völkerkunde and in production debris and unfinished objects in the Uummannaq midden. One museum object that can be traced to the Uummannaq mission with certainty is a traditional triangular soapstone lamp brought home by the missionary Otto Heincke in 1900. A unique object that also left Greenland with some of the last Moravians was an octagonal soapstone foot for the Christmas tree engraved with the letters "E.B.," "M.L." and the year "1900" (Lund Jensen et al., 2011:262). Another object made to fit European tastes was a circular, thin-walled bowl made of a fine-grained pale green steatite (Fig. 9). According to the museum inventory, this bowl was a gift from the renowned Moravian missionary David Crantz to one of his fellow brethren, Johan Gottlieb Adolf Riegel (Lund Jensen et al., 2011:259). The material is visually identical to soapstone found in a deposit on the east side of Uummannaq Island, a stone source that is still in use today (Toft, 2011). Although Crantz stayed only at Neu Herrnhut during the winter of 1761-62 (Lund Jensen et al., 2011:256), the bowl was very likely made on Uummannaq, or of material from that island. The same goes for another lamp donated to the museum by Crantz (Inv. No 67820), which has an unusual form (Lund Jensen et al., 2011:256). This lamp is drop-shaped, with a handle, and its inner edge is heart-shaped because of the form of its wick-ledge. Additional objects of the same material include three paperweights, one with a seal figure handle, one with an egg-shaped handle, and the last with a 
handle of black painted wood (Lund Jensen et al., 2011:258, 262). The latter (Inv. No 67830) has a form that further connects it to Uummannaq, where the broken corner of an almost identical unfinished paperweight was found in the Inuit midden. On its polished surface, the letters "QOL... $æ M$ " were engraved with thin letters. The inscription has no meaning in German, Danish, or Greenlandic, but is a trace of another skill taught to the Inuit at the Danish and Moravian missions.

Literacy was important, as it enabled the education of local catechists and people to read the scriptures and psalms, which had already been translated into Greenlandic in the early 18th century. The teaching of reading and writing also manifests itself in the landscape at Uummannaq, in the form of the school building lying next to the chapel (Fig. 6: Feature B) and in the midden material, where fragments of slate writing plates and pencils have been found. Even a slate roof tile was reused as a writing plate. Broken slate pencils in the layers overlying those of the Moravian mission show that this activity continued after the departure of the Moravians.

One last object from the midden with engraved numbers brings us even closer to one of the persons living at Uummannaq and the cultural processes at the missions. This is a flat steatite figurine, $3.9 \mathrm{~cm}$ long, with incised facial features: eyes, eyebrows. and nose (Fig. 10). Judging by its highly accentuated hips, the figurine probably portrays a woman. Its flat form and depiction of facial features make it very unusual compared to contemporary Greenlandic figurines of bone and wood and may have been inspired by European artwork. The numbers incised on its front and back make the figurine even more unusual. The number "509" is seen on the front across the stomach and is mirrored on the back at the same height. On the back, the numbers " 30 " and " 40 " have also been incised on the figurine's neck. Obviously the mirrored number must be of importance and can be related to Uummannaq through Moravian records (NKA, 1877). The entry number 509 identifies the woman as Agathe, who was born in Neu Herrnhut in 1877, 16 years after the founding of the Uummannaq mission. Her father Eugenius was from the island, and even though he married the woman Anne from Neu Herrnhut, the family lived most of their life at Uummannaq. The records also reveal that Agathe later married another Uummannaq resident, Johan Kristian Anton Kloster. The wedding was held in 1904, shortly after the departure of the Moravians, whereas the figurine originates from a layer contemporary with the mission phase at Uummannaq. But even so, Johann may have carved the figurine outside his house, while his thoughts were wandering to Agathe. Whoever the maker of the figurine was, he must have known Agathe's entrance number in the registers, which were not only a European administrative tool, but perhaps also a part of an individual's identity even at the Greenlandic missions. In the cemetery of the Danish Moravian mission called Christiansfeld, people's entrance numbers were engraved on their gravestones. The Agathe

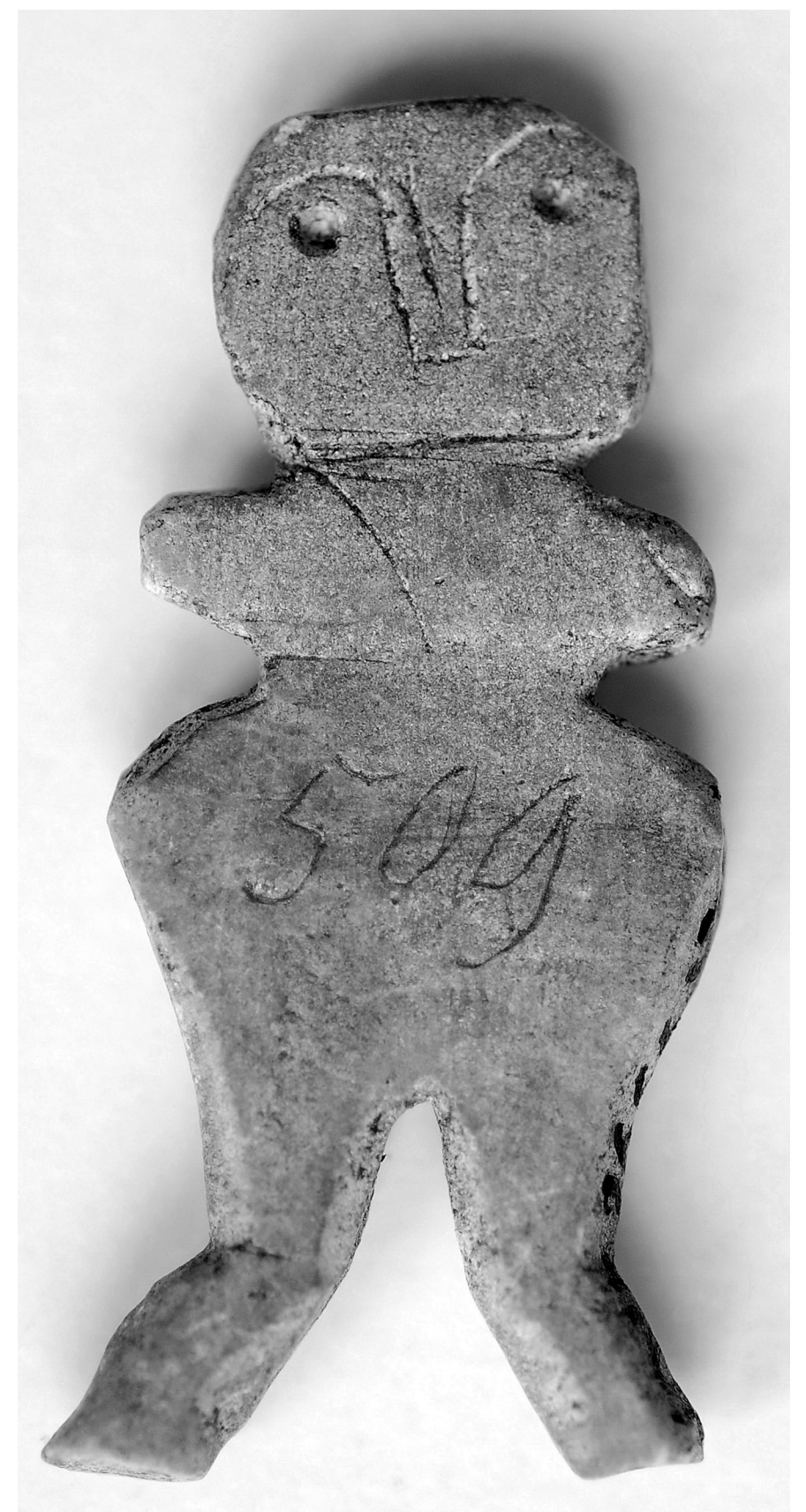

FIG. 10. Soapstone figurine found in the Uummannaq midden. Length: $3.9 \mathrm{~cm}$. Photo: P.A. Toft.

figurine is a prominent example of a transculturated object and practice that evolved in the meeting between Inuit and Europeans at contact zones like the Moravian missions.

\section{CONCLUSIONS}

Encounters between Greenlandic Inuit and Moravian missionaries at missions and settlements involved a process of transculturation, in which settlement layout, cemetery location, grave forms, and material culture were transformed. The result was often somewhere between 
Moravian ideals and Inuit traditions, or the coexistence of the two, which is evident at the missions of Lichtenfels and Uummannaq, as well as the Kangillermiut settlement.

In mission layout, the church was central, but gardens could not always be placed at its front according to Moravian ideals, and the view to church and garden was sometimes obstructed by Inuit houses. The location of the missions was often a compromise between protection from winds and stream, hunting potential, and the distance to the nearest trading post. In addition, settlement layout was also adapted to the local terrain, which became the scene for new feature types, including churches, gardens, wells, and stone-built paths. Evidence from the three sites further suggests that the distance between Moravian settlements and their associated cemeteries diminished from the 18th to the 19th century as a result of slow change of Inuit traditions. However, stone graves were still used alongside turf and inhumation graves introduced in the 19th century. And old Inuit traditions such as grave goods and multiperson burials seemed to continue into the second half of the 18th and the late 19th century, respectively.

Both Inuit and Moravian material cultures were affected by the cultural encounters. The Moravians not only used and brought traditional Inuit objects to Europe, but their presence also resulted in an Inuit souvenir production of European objects in local materials and representing Inuit items and traditional life. These souvenirs were sometimes made of materials only available locally, like the steatite and lyme grass on Uummannaq Island. Such objects often assumed European forms like open-work grass baskets or European style steatite paperweights or bowls. Apart from the ivit grasswork, a tradition alive today, the Moravian presence is equally visible in Inuit material culture at the missions. Writing slates and pencils, as well as steatite objects with inscriptions, reveal mission activities, in this case, teaching. Furthermore, objects not available at RGTD stores, such as the European shoes found in the Uummannaq midden, demonstrate trade between missionaries and their local congregations. Sometimes the reciprocal transculturation at Moravian sites is even revealed in a single object, such as the Agathe figurine that was made of local raw material, with facial features and a Moravian birth number that are neither totally European nor totally Inuit.

\section{ACKNOWLEDGEMENTS}

Warm thanks to Genevieve LeMoine and Susan Kaplan at the Peary-MacMillan Arctic Museum, who have generously shared their knowledge of publications on Labradorean and Alaskan grasswork and provided articles not available in Denmark. Special thanks go to my fellow field workers Pauline Knudsen, Pernille Ødegaard, Kirstine Eiby Møller, Hans Henrik Berthelsen, Hans Christian Gulløv, Jens Winther Johannsen, and Jesper Langkilde for many enjoyable hours in their company. Further thanks to project leader Pauline Knudsen for her generous permission to publish revised site plans for the Lichtenfels and Kangillermiut sites. Funding of the fieldwork was provided by the Committee for Scientific Research in Greenland (KVUG) and the Velux Foundation.

\section{REFERENCES}

Bendixen, O. 1917. Den Grønlandske General-Takst og Handel og Omsætning ved kolonierne i gamle Dage [The Greenlandic price lists and trade and turnover at the colonies in the old days]. Det Grønlandske Selskabs Aarsskrift 1917:1 -9.

_ _ 1921. Bopladser i Godthaab Distrikt [Settlements in the Godthaab District]. In: Amdrup, G.C., Bobé, L., Jensen, A.D.S., and Steensby, H.P., eds. Grønland i tohundredeaaret for Hans Egedes landing [Greenland at the 200 year anniversary of Hans Egedes landing], Bind II. Meddelelser om Grønland 61:176-269.

Bobé, L. 1921. Historie [History]. In: Amdrup, G.C., Bobé, L., Jensen, A.D.S., and Steensby, H.P., eds. Grønland i tohundredeaaret for Hans Egedes landing [Greenland at the 200 year anniversary of Hans Egedes landing]. Bind II. Meddelelser om Grønland 61:270-296.

Cabak, M., and Loring, S. 2000. "A set of very fair cups and saucers": Stamped ceramics as example of Inuit incorporation. International Journal of Historical Archaeology 4(1):1 - 34 . https://doi.org/10.1023/A:1009501426611

Christensen, B. 1972. Grønlandske ivit-kurve [Greenlandic lyme grass baskets]. Tidsskriftet Grønland 1972 (1):23-31.

Crantz, D. 1765. Historie von Grönland I-III. Barby: Heinrich Detlev Ebers.

Deagan, K. 1998. Transculturation and Spanish American ethnogenesis: The archaeological legacy of the Quincentenary. In: Cusick, J.G., ed. Studies in culture contact: Interaction, culture change and archaeology. Carbondale: Center for Archaeological Investigations, Southern Illinois University. $23-43$.

Gilberg, R., and Petersen, R. 1991. Death and burial. In: Hart Hansen, J.P., Meldgaard, J., and Nordqvist, J., eds. The Greenland mummies. Montreal: McGill-Queen's University Press. 54-63.

Gulløv, H.C. 1983. Nuup kommuneani qangarnitsanik eqqaassutit - inuit-kulturip nunaqarfii. Fortidsminder i Nuuk kommune - inuit-kulturens bopladser [Heritage sites in Nuuk municipality - settlements of the Inuit culture]. Nuuk: Kalaallit Nunaata Katersugaasivia \& Nationalmuseet.

1997. From Middle Ages to colonial times: Archaeological and ethnohistorical studies of the Thule culture in South West Greenland 1300-1800 AD. Meddelelser om Grønland, Man \& Society 32. Copenhagen: The Commission for Scientific Research in Greenland.

Haagen, B. 2007. Kurve og andre arbejder af grønlandsk marehalm. Et upåagtet grønlandsk kunsthåndværk [Baskets and other works of Greenlandic lyme grass. An unnoticed Greenlandic craft]. Tidsskriftet Grønland 2007 (4):190-196. 
Hansen, S. 1893. Bidrag til Vestgrønlændernes Anthropologi [Contributions to the anthropology of the West Greenlanders]. Meddelelser om Grønland 7:163-250.

Hawkes, E.W. 1916. The Labrador Eskimo. Geological Survey Memoir 91, Anthropological Series No. 14. Ottawa: Government Printing Bureau.

Holtved, E. 1944. Archaeological investigations in the Thule District. Meddelelser om Grønland 141(1-2). Copenhagen: C.A. Reitzels Forlag.

Hyde, A., Baldwin, A.C., and Gage, W.L. 1874. The frozen zone and its explorers: A comprehensive record of voyages, travels and discoveries, adventures and whale-fishing in the Arctic for one thousand years. Hartford, Connecticut: Columbian Book Company.

Igloliorte, H. 2013. Nunatsiavummi Sananguagusigisimajangit/ Nunatsiavut art history: Continuity, resilience, and transformation in Inuit art. PhD thesis, Carleton University, Ottawa, Ontario.

Kleivan, I. 1983. Herrnhuterne eller brødremenigheden i Grønland 1733-1900 [Moravians in Greenland 1733-1900]. Tidsskriftet Grønland 1983 (8-10):221-235.

Knudsen, P., Toft, P.A., Koch Madsen, C., Matthiesen, H., Hollesen, J., Kroon, A., Møller, A.B., Pedersen, M.W., et al. 2014. People of all times, field report, January 2014. Unpubl. field report. Available at SILA - Arctic Centre at the Department of Modern History and World Cultures, The National Museum of Denmark, 1220 Copenhagen K, Denmark.

Kragh, P. 1875. Udtog af Missionær P. Kraghs Dagbog 1ste Deel [Extract of missionary P. Kragh's diary part 1]. Haderslev.

Lee, M. 2004. Weaving culture: The many dimensions of the Yup'ik Eskimo mingqaaq. Études/Inuit Studies 28(1):57-67. https://doi.org/10.7202/012639ar

Loring, S., and Arendt, B. 2009. “...they gave Hebron, the city of refuge..." (Joshua 21:13): An archaeological reconnaissance at Hebron, Labrador. Journal of the North Atlantic, Special Vol. $1: 33-56$. https://doi.org/10.3721/037.002.s106

Lund Jensen, E., Raahauge, K., and Gulløv, H.C. 2011. Cultural encounters at Cape Farewell: The East Greenlandic immigrants and the German Moravian mission in the 19th century. Meddelelser om Grønland 348, Man and Society 38. Copenhagen: Museum Tusculanum Press.

Mason, O.T. 1904. Aboriginal American basketry. Studies in a textile art without machinery. Annual Report of the Board of Regents of the Smithsonian Institution showing the Operations, Expenditures, and Conditions of the Institution for the Year ending June 30, 1902. Report of the U.S. National Museum for 1902. Washington, D.C.: Government Printing Office. $185-548$.

McGrath, J. 1979. Labrador crafts: Grass work. Them Days $5(1): 42-59$.
Nelson, L.H. 1968. Nail chronology as an aid to dating old buildings. Technical Leaflet 48. Nashville, Tennessee: American Association for State and Local History.

NKA (Nunnatta Katersugasiva allagaateqarfia) n.d. [ca. 1900]. Fiskenæsset præstegæld 1895-1949. Designationsprotokol [Fiskenæsset Parish 1895-1949. Designation protocol]. NKA 22.06.02-3.1.1.0. Nuuk: National Archive of Greenland.

1877. Herrnhut Minesterialbog 1809-1900. 2. Bog. I [Moravian Minesterial register 1809-1900. 2nd Book, I]. NKA 22.06.04. Nuuk: National Archive of Greenland.

RA (Rigsarkivet). 1834. Rentekammeret, Danske Afdeling. Tabelkommissionen. Folketælling 1834, Grønland [Royal Exchequer. Danish Department. Committee of Tables. Census 1834, Greenland]. RA 303.1. Copenhagen: National Archive of Denmark.

. 1845. Rentekammeret, Danske Afdeling. Tabelkommissionen. Folketælling 1845, Grønland [Royal Exchequer. Danish Department. Committee of Tables. Census 1845, Greenland]. RA 303.3. Copenhagen: National Archive of Denmark.

. 1850. Danmarks Statistik. Folketælling 1850, Grønland [Statistics Denmark. Census 1850, Greenland]. RA 1308.4. Copenhagen: National Archive of Denmark.

- 1860. Danmarks Statistik. Folketælling 1860, Grønland [Statistics Denmark. Census 1860, Greenland]. RA 1308.6. Copenhagen: National Archive of Denmark.

- 1870. Danmarks Statistik. Folketælling 1870, Grønland [Statistics Denmark. Census 1870, Greenland]. RA 1308.7. Copenhagen: National Archive of Denmark.

- 1901. Danmarks Statistik. Folketælling 1901, Grønland [Statistics Denmark. Census 1901, Greenland]. RA 1308.8. Copenhagen: National Archive of Denmark.

—. 1911. Danmarks Statistik. Folketælling 1911, Grønland [Statistics Denmark. Census 1911, Greenland]. RA 1308.9. Copenhagen: National Archive of Denmark.

—. 1945. Danmarks Statistik. 1930-1950. Folketælling 1945, Grønland [Statistics Denmark. 1930-1950. Census 1945, Greenland]. RA 1308.2. Copenhagen: National Archive of Denmark.

Toft, P.A. 2011. Uummannaq - fedtstenen og menneskene [Uummannaq - the steatite and people]. Tidsskriftet Grønland 59(4):184-295.

Toft, P.A., and Gulløv, H.C. 2011. Fedtstensudnyttelse på Uummannaq, Nuuk-fjorden og rekognoscering efter norrøne lokaliteter i Kapisillit-fjorden. SOAP 2007, del 1 [Steatite use at Uummannaq, Nuuk fjord and survey of Norse sites in the Kapisillit fjord]. SILA Feltrapport 32. Copenhagen: SILA Arktisk Center ved Nationalmuseets Etnografiske Samling. $54 \mathrm{p}$.

http://natmus.dk/fileadmin/user_upload/natmus/forskning/ dokumenter/SILA/Feltrapport_32.pdf 